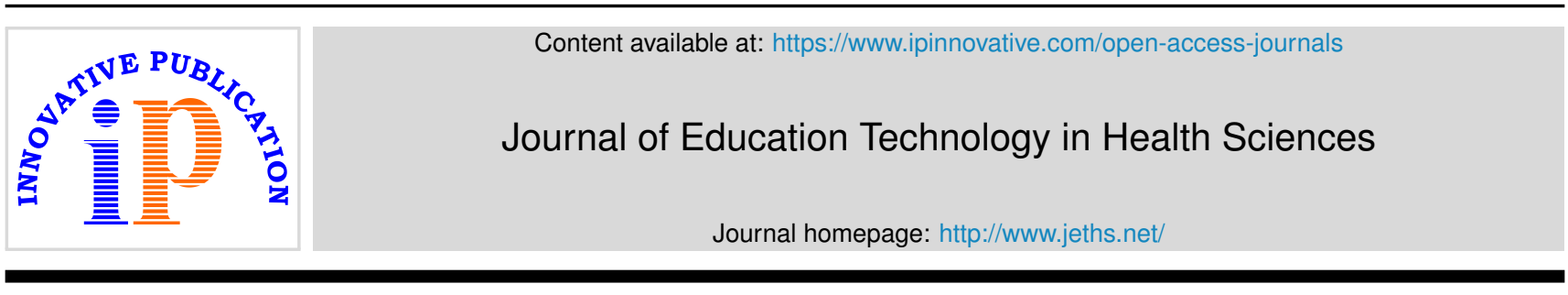

\title{
Editorial
}

\section{Challenges in conducting educational research during Covid pandemic}

\author{
Meenal Kulkarni ${ }^{1, *}$ \\ ${ }^{1}$ Dept. of Community Medicine, N. K. P. Salve Institute of Medical Sciences \& RC \& LMH, Nagpur, Maharashtra, India
}

A R T I C L E I N F O

Article history:

Received 28-04-2021

Accepted 30-04-2021

Available online 17-05-2021
(C) This is an open access article distributed under the terms of the Creative Commons Attribution License (https://creativecommons.org/licenses/by/4.0/) which permits unrestricted use, distribution, and reproduction in any medium, provided the original author and source are credited.
Covid-19 is the disease caused by a new corona virus called SARS-CoV-2. World Health Organization first learned of this new virus on 31 December 2019, following a report of a cluster of cases of 'viral pneumonia' in Wuhan, People's Republic of China. It has spread to all countries with huge morbidity and mortality. The COVID19 pandemic has led to a dramatic loss of human life worldwide and presents an unprecedented challenge to public health, food systems and the world of work. COVID19 has changed the way we do almost everything.

Covid pandemic has also caused a big impact on ongoing educational research. Educational researchers are facing many challenges while doing research.

1. Safety of participants and staff-Many academic medical centers have paused research to eliminate non-essential contact to protect study participants and research staff.

2. Reallocation of job responsibilities-With increasing pressure of pandemic on health care system, research personnel have been reallocated to other assignments.

3. Covid infection among research staff and participants has limited research workforce.

4. Limitations in conducting online research -In covid pandemic focus of research is shifted to online research by using google forms, voice calls and video calls. But there are many limitations in conducting online

* Corresponding author.

E-mail address: meenalkulkarni76@gmail.com (M. Kulkarni). research. Difficulties faced due to lack of digital literacy or access to digital technologies by researchers as well as participants. Getting access to strong internet connection to carry voice or video calls is difficult. Communicating through google forms, voice and video calls makes research really difficult as compared to face to face contact.

5. Research fund availability-As Covid pandemic is a burning public health problem, the focus of research in general is shifted to covid related research. There is limitation in getting funds and most of research funds which are available have been diverted for covid research.

Challenges are many but there are some Solutions to overcome challenges such as providing training to researchers as well as research participants to use technology, assigning research funds to enhance access to technology such as better internet coverage, considering secondary data instead of data collection etc.

\section{Author biography}

Meenal Kulkarni, Associate Professor

Cite this article: Kulkarni M. Challenges in conducting educational research during Covid pandemic. J Educ Technol Health Sci 2021;8(1):1-1. 